\title{
AL-QUR'AN DAN MASA DEPAN MANUSIA (PERSPEKTIF SOSIOLOGI AGAMA)
}

\author{
Anis Ulfiyatin \\ Dosen Sekolah Tinggi Ilmu Al-Qur'an dan Sains Al-Ishlah (STIQSI) \\ Sendangagung Paciran Lamongan \\ anisulfiyatin@gmail.com
}

\begin{abstract}
Abstrak
Kajian ini memfokuskan pembahasan tentang dampak dari wabah pandemi Covid-19 dan pengaruhnya terhadap sektor agama serta perilaku keberagamaan seseorang di masa pandemi. Bahwa dengan adanya kedaruratan kondisi sosial, ekonomi, kesehatan, pendidikan, dan budaya secara global, hal ini memunculkan pola-pola adaptasi dan perilaku keberagamaan yang baru di tengah-tengah masyarakat. Permasalahannya kemudian, akankah pola adaptasi yang baru ini mampu merombak tatanan nilai dan norma dalam agama Islam yang sudah ada. Selanjutnya, ketika pada akhirnya muncul tatanan nilai dan norma baru, akankah struktur sosial keagamaan yang telah ada selama ini menjadi disfungsi dan menggiring pada mati dan hilangnya institusi agama di masyarakat kita hari ini. Terakhir, bagaimana dan sejauh mana peran ajaran agama Islam dengan nilainilai Al-Qur'an-nya terus mampu menjadi "jaminan” keselamatan bagi masa depan umat manusia?.Tujuan: Kajian ini bertujuan untuk mengeksplorasi penerapan kebijakan penanggulangan Covid-19 di Indonesia di bidang keagamaan, juga untuk melihat sejauh mana konsep ajaran Islam yang bersandar pada nilai-nilai Al-Qur'an mampu menjadi solusi atas permasalahan dalam menghadapi wabah pandemi Covid-19 di Indonesia, serta, bagaimana perspektif sosiologi agama menjelaskan masa depan agama Islam dan nilai-nilai Al-Qur'an ini di masa depan. Hasil dan Simpulan: (1) Kajian ini menyimpulkan bahwa betapa wabah Covid-19 ini dengan dahsyatnya mampu meluluhlantakkan tatanan nilai dan norma keberagamaan masyarakat di Indonesia. (2) Bahwa dengan adanya pola adaptasi yang baru dan perilaku keberagamaan masyarakat dalam menghadapi pandemi Covid-19 ini, menggiring kita pada suatu proses redefinisi atas konsep agama itu sendiri. Selanjutnya, pandemi Covid-19 ini nyatanya juga membawa kita untuk kembali pada suatu upaya untuk proses pemurnian kembali ajaran agama Islam, yakni perilaku keberagamaan yang murni dan bersumber pada nilai-nilai dasar Al-Qur'an. (3) selanjutnya, kajian ini membawa kita bersama pada sebuah simpulan tentang masa depan manusia yang mengarah pada terbentuknya pola tatanan nilai dan norma baru yang justru bersumber dari AlQur'an, kitab suci umat agama Islam. Sebuah analisa sosiologis yang ditopang dan diperkuat dengan pemikiran-pemikiran tokoh sosiologi awal sebagaimana dalam
\end{abstract}


kajian Suicide oleh seorang Emile Durkheim dan kajian tentang Protestant Ethics oleh seorang Max Weber dalam lingkup kajian sosiologi agama.

Kata Kunci: Covid-19, Adaptasi sosial, perilaku keberagamaan.

\section{A. Pendahuluan}

Selama hampir dua tahun terakhir, hampir seluruh masyarakat dunia disibukkan dengan meluasnya wabah pandemi Covid-19. Wabah ini pertama kali muncul di China, hingga akhirnya meluas ke berbagai negara di Eropa, Afrika, hingga wilayah Asia. Meskipun bukan negara pertama yang terdampak, kasus di negara Italia bahkan begitu masif sehingga menelan korban jiwa hingga ribuan, dan menjadikan Italia sebagai negara dengan rasio angka kematian tertinggi. Sama halnya dengan beberapa negara di negara-negara timur tengah yang juga ikut tersasar kasus serupa. Bahkan, pemerintah Saudi Arabia turut merespon perkembangan kasus pandemi ini dengan sangat serius. Salah satu portal berita online mengabarkan bahwa sejak hari Jumat (6/3/2020), Masjidil Haram atau area Ka'bah resmi ditutup untuk kunjungan jemaah umrah dari berbagai negara. Kabarnya, bahkan penguasa negara monarki ini mengeluarkan keputusan agar pelaksanaan kegiatan haji yang merupakan praktik peribadatan akbar yang digelar rutin setiap tahunnya, juga akan ditutup di tahun ini.

Meskipun kejadian serupa bukan kali pertama dalam sejarah, tetapi hal ini cukup menjadi catatan penting betapa dahsyatnya wabah pandemi Covid-19 ini, bahwa ia mampu meluluhlantakkan tatanan sosial keagamaan yang selama ini nyaris tidak terpapar oleh isu apa pun yang bergejolak di seluruh penjuru dunia.

Di sektor ekonomi, neraca perdagangan hampir seluruh negara di dunia mengalami penurunan drastis akibat wabah pandemi Covid-19 ini. Di Indonesia sendiri, dampak terburuknya adalah, ratusan buruh dan tenaga kerja yang terpaksa harus kehilangan pekerjaannya karena PHK oleh pihak perusahaan. Begitu juga dengan berbagai sektor lain yang membawa pengaruh pada hajat hidup masyarakat luas, juga tidak luput dari dampak wabah pandemi Covid-19 ini. baik itu lembaga pendidikan, sistem politik dalam negeri, maupun lembaga hukum dan peradilan. 


\section{Anis Ulfiyatin}

Di Indonesia sendiri, dampak dari wabah pandemi Covid-19 ini tidak kalah dahsyatnya. Bahkan karena pentingnya proses memutus rantai penyebaran wabah Covid-19 ini, pemerintah Indonesia melalui kementerian agamanya membuat maklumat agar sementara waktu, seluruh kegiatan keagamaan yang melibatkan jemaah masjid, untuk sementara harus diberhentikan. Selanjutnya, pemerintah menghimbau agar seluruh kegiatan peribadatan ditunda dan cukup dilaksanakan di rumah masing-masing.

\section{B. Respon Masyarakat-Agama di Indonesia}

Belakangan, Indonesia sebagai salah satu negara yang mayoritas penduduknya beragama Islam, pun merespon wabah Covid-19 ini dengan cukup keras. Bahwa kemudian para pemimpin lembaga keagamaan merasa perlu untuk merespon peristiwa pandemi ini dengan mengeluarkan beberapa fatwa agama yang berisi beberapa keputusan yang luar biasa. Salah satunya adalah keputusan ijtima ' ulama yang membolehkan para pengurus masjid dan juga umat muslim di Indonesia untuk tidak menyelenggarakan kegiatan keagamaan berupa salat Jumat berjemaah, demikian juga dengan kegiatan salat berjemaah setiap harinya. Demikian juga dengan berbagai agenda kegiatan kajian keagamaan yang justru diharapkan agar dibatalkan untuk batas waktu yang belum ditentukan.

Menariknya lagi, praktik-praktik keagamaan lain yang bersifat khusus dan menyentuh ranah privat pun, turut serta dirombak sedemikian rupa, hanya dengan alasan, agar proses penyebaran virus Covid-19 ini bisa dihentikan dan tidak semakin meluas di Indonesia. Contohnya saja praktik keagamaan dalam syariat Islam berupa anjuran kepada sesama penganutnya untuk saling berjabat tangan, sebuah ritual suci yang tidak hanya bermakna sebagai sarana berkomunikasi dan bersosialisasi dengan sesama individu dalam masyarakat sebagai makhluk sosial, tetapi lebih dari itu, ritual jabat tangan dalam agama Islam bermakna juga sebagai salah satu praktik pelaksanaan syariat yang bertujuan untuk; (1) sarana meleburkan dosa bagi penganut ajarannya, juga (2) menambah keberkahan dalam usia bagi para penganut agama Islam yang mempraktikkannya, bahwa melalui tindakan berjabat 
tangan dalam setiap kegiatan sosial (silaturahmi) mengandung harapan atas keselamatan dan keberkahan bagi masing-masing individu yang melaksanakannya.

Sejak isu tentang pandemi Covid-19 ini mewabah dan semakin meluas di Indonesia, praktik syariat keagamaan dalam ajaran Islam ini justru dihindari untuk dilaksanakan, bahkan mendapatkan legitimasi kuat dari hampir seluruh pemuka agama Islam yang ada. Dari perspektif ilmu kedokteran modern sendiri, pelarangan untuk berjabat tangan ini cukup rasional untuk dilaksanakan mengingat salah satu mekanisme penyebaran dan penularan virus Covid-19 ini adalah melalui sentuhan antar anggota tubuh, khususnya telapak tangan sebagai media yang paling riskan dalam proses penularan.

Turut merespon realitas sosial yang ada, praktik peribadatan lain berupa pengucapan kalimat (lafal) azan yang biasa diperdengarkan di setiap masjid, sebagai pusat kegiatan keagamaan bagi umat beragama Islam, pun diganti dengan kalimat (lafal) "khusus". Sebuah mekanisme luar biasa yang ditempuh oleh lembaga agama. Terlebih, secara historis, agama Islam sendiri selama ini dikenal dengan syariat agamanya yang pakem dan memiliki tafsir tunggal dan kuat atas ajaran agamanya, serta berbagai aturan-aturan keagamaan yang tidak mudah diintervensi oleh berbagai peristiwa (sosial, politik, budaya, ekonomi) yang ada.

Praktik peribadatan di beberapa agama lain pun ternyata tidak jauh berbeda. Praktik ritual keagamaan dalam agama Kristen misalnya. Turut merespon peristiwa yang sama, para pengurus gereja dan pemuka agama Kristen di beberapa wilayah di Indonesia bahkan telah melaksanakan ritual ibadah gereja hari Minggu mereka secara daring (online). Bahwa ritual keagamaan yang biasanya mengharuskan para penganut ajarannya untuk berkumpul bersama di gereja, tempat ibadah yang dipercaya memiliki derajat "suci" bagi para pemeluknya, dalam rangka mendengarkan dan atau membaca teks suci agama mereka dengan dipimpin langsung oleh seorang pastur/pendeta di hadapan jemaahnya, mendadak "boleh" dilaksanakan dengan cara yang tidak biasa.

\section{Tujuan}




\section{Anis Ulfiyatin}

Berangkat dari latar belakang masalah tersebut, kajian ini menjadi penting untuk dilakukan guna mengeksplorasi penerapan kebijakan penanggulangan Covid-19 di Indonesia di bidang keagamaan, juga untuk melihat sejauh mana konsep ajaran Islam yang bersandar pada nilai-nilai Al-Qur'an mampu menjadi solusi atas permasalahan dalam menghadapi wabah pandemi Covid-19 di Indonesia, serta, bagaimana perspektif sosiologi agama menjelaskan masa depan agama Islam dan nilai-nilai Al-Qur'an ini di masa depan.

\section{Rapuhnya Ritual Keagamaan}

Dalam kajian sosiologi agama sendiri, konsep ritual agama dimaknai sebagai serangkaian praktik kegiatan yang dilaksanakan terutama untuk tujuan simbolis (Tualeka, 2011: 13). Tindakan sosial ini dilaksanakan berdasarkan suatu agama atau bisa juga berdasarkan tradisi dari satu komunitas tertentu yang ada di masyarakat. Oleh karena itu, praktik ritual agama ini tidak dapat dilaksanakan secara sembarangan oleh para penganutnya, karena dalam masing-masing lembaga agama, telah juga dilengkapi dengan seperangkat tata cara, norma, dan aturan yang telah ditentukan sebelumnya.

Objek kajian sosiologi agama tidak memfokuskan pada hakikat agama, tetapi kepada masyarakat-agama, berikut menyelidiki tempat agama dan penganutnya oleh masyarakat dalam kehidupan sosial. Lebih jauh, objek sosiologi agama adalah interelasi (hubungan timbal balik) antara agama dan masyarakat, sehingga analisanya akan diarahkan untuk dapat menjelaskan bagaimana unsur-unsur kepercayaan, ritual dan praktik peribadatan, mampu untuk mempengaruhi pembentukan kepribadian pemeluk-pemeluknya. Selanjutnya, diharapkan bisa menggeneralisasikan bagaimana ekspresi keberagamaan penganut ajarannya melalui berbagai tingkah laku dan tindakan sosial masyarakat-agamanya.

Berdasarkan penjelasan tersebut, dapat dipahami bahwa posisi ritual keagamaan dan bagaimana ia (praktik ibadah) dimaknai oleh masyarakat-agama adalah variabel yang sangat berpengaruh terhadap tinggi rendahnya tingkat religiusitas seorang individu dalam masyarakat, pun terhadap tinggi rendahnya 
derajat legitimasi yang dimiliki oleh masing-masing agama di mata para penganut ajarannya. Para penganut ajaran agama yang tidak ikut serta menjalankan praktik ritual keagamaan dalam suatu masyarakat, bisa dikatakan sebagai salah satu indikator utama yang menunjukkan rendahnya derajat legitimasi yang dimiliki oleh agama tersebut di mata masyarakat-agamanya.

Sebaliknya, besarnya pengaruh agama dalam suatu masyarakat, pun dapat diukur, salah satunya, dari seberapa banyak ritual keagamaan yang dilaksanakan dan ditaati, serta dilestarikan melalui mekanisme pelembagaan khusus, oleh para masyarakat-agamanya.

Melalui hadirnya peristiwa sosial berupa pandemi virus Corona (Covid-19) di hampir seluruh penjuru wilayah di dunia hari ini, masyarakat dunia seakan digiring pada sebuah kesimpulan akhir yang mencengangkan. Sebuah pesan yang bahkan mampu meluluhlantakkan konsep sakral dan keyakinan bersama atas nama agama. Bahwa ritual keagamaan yang berbasis pada ajaran Tuhan sekalipun, ternyata mampu berada pada posisi yang sangat rapuh.

Sebagaimana pada uraian di atas, bagaimana dahsyatnya Covid-19 ini dalam membubarkan jemaah masjid, anggota jemaah gereja, mampu menghentikan prosesi akbar tahunan berupa ibadah haji dan umrah, menutup banyak masjid dan gereja, merubah tata cara tertentu dalam prosesi peribadatan, hingga mampu merubah hukum salaman dalam praktik ajaran agama islam, dari yang sebelumnya dianjurkan, hari ini justru menjadi sesuatu yang perlu untuk dihindari bersama.

\section{E. Telaah Sosiologi Atas Kondisi Keberagamaan Masyarakat Hari ini}

Oleh khalayak luas, kajian sosiologi dianggap sebagai sebuah fenomena yang relatif modern. Bahwa seluruh kajian ilmu sosial khususnya yang menggunakan perspektif sosiologi Semata-mata adalah fenomena barat. Tidak jauh berbeda dengan pembahasan tentang temuan-temuan ilmiah modern lainnya yang juga didominasi oleh ilmuwan-ilmuwan yang berasal dari negara barat itu sendiri. 


\section{Anis Ulfiyatin}

Kontras dengan realitas tersebut, secara terbatas, kajian dari perspektif Islam justru menyuguhkan data yang berkebalikan. Bahwa hampir semua temuan ilmiah modern hari ini adalah hasil dari kerangka berpikir para tokoh-tokoh muslim pada masa itu. Mulai dari bapak ilmu kedokteran, peletak dasar teori optik modern, penemu teknologi pesawat terbang, dan termasuk juga, sosiolog pertama yang tidak lain adalah seorang sarjana muslim, yakni Ibnu Khaldun.

Ibnu Khaldun adalah seorang ilmuwan muslim yang bernama Abdul Rahman Ibn Khaldun. Lahir pada tahun 1332 di Tunisia, Afrika Utara. Seorang sarjana yang berasal dari keluarga terpelajar. Khaldun masuk di sekolah Al-Qur'an dan banyak mempelajari matematika dan sejarah. Latar belakang ini juga yang mengantarkannya menjadi seorang sosiolog yang menghabiskan banyak waktunya untuk mengkaji masyarakat dari perspektif sejarah sebagaimana disiplin yang ia kuasai.

Khaldun menghabiskan waktunya selama hampir 2 dekade di dunia politik. Beberapa jabatan di lembaga pemerintahan pernah ia duduki. Sebelum akhirnya ia kembali ke Afrika utara dan mendedikasikan waktunya untuk melakukan berbagai riset sosial dan menulis selama kurang lebih 5 tahun. Maha karyanya adalah buku Muqaddimah Ibn Khaldun, satu dari beberapa rujukan penting dalam disiplin sosiologi di kemudian hari.

Ketika pada akhirnya kajian sosiologi berkembang, muncullah kajian tentang masyarakat yang menggunakan berbagai perspektif yang berbeda. Misalnya, kajian sosiologi politik, sosiologi pendidikan, sosiologi hukum, dan juga kajian sosiologi agama.

Perspektif sosiologi agama sendiri bertujuan untuk melihat bagaimana agama mempengaruhi interpretasi terhadap berbagai problem sosial yang ada di masyarakat. Bahwa realitas sosial yang ada di masyarakat adalah akibat dari perilaku keberagamaan yang dipraktekkan masyarakat. Secara lebih sederhana, telaah sosiologi agama difokuskan pada analisis tentang expression of religious experience. Selanjutnya, dalam praktiknya di lapangan, seorang sosiolog harus mampu memposisikan diri diantara dua logika pemikiran: subjektif VS objektif. 


\section{F. Pengaruh Agama Terhadap Kondisi Sosial-Ekonomi Masyarakat}

Adalah seorang Emile Durkheim, salah satu tokoh sosiologi klasik yang melakukan kajian sosiologis tentang bagaimana dan apa hubungan antara kasus bunuh diri dengan perilaku penghayatan keberagamaan dalam suatu masyarakat. Kajian tersebut ditulis dengan apik dalam laporan penelitiannya yang berjudul Suicide, sebuah tulisan yang kemudian banyak diperbincangkan dan digunakan sebagai rujukan untuk kajian serupa di berbagai belahan dunia.

Bahwa berbagai kasus bunuh diri yang terjadi di beberapa negara yang menjadi lokasi penelitiannya, bukan kasus individu karena faktor psikologis, tekanan ekonomi, politik dan hukum, atau bukan juga karena faktor medis. Tetapi adalah kasus sosial yang berkaitan erat dengan kuat atau longgarnya ikatan sosial (solidaritas) yang ada di masyarakat.

Oleh Durkheim, hal ini dijelaskan bahwa tinggi rendahnya kasus bunuh diri yang terjadi dapat dipengaruhi oleh ada tidaknya jiwa kelompok (collective consciousness) yang dimiliki masing-masing individu dalam masyarakat. Collective consciousness inilah yang akan menentukan mampu tidaknya menciptakan kondisi masyarakat yang solid dan terintegrasi dengan baik. Artinya, semakin kuat derajat integrasi sosial dalam masyarakat, kemungkinan kasus bunuh diri akan semakin menurun, begitu pula sebaliknya, jika masing-masing entitas masyarakat tidak memiliki Collective consciousnessyang baik, maka integrasi sosial masyarakat akan sulit tercipta, dan akibatnya adalah, meningkatnya kasus bunuh diri di tengah-tengah masyarakat.

Tokoh sosiologi lain, Max Weber, muncul juga dengan kajian di bidang sosiologi agama. Yakni, analisis tentang keterkaitan antara nilai-nilai agama dengan semangat kapitalisme di bidang ekonomi atau lebih dikenal dengan konsep etika protestan (the protestant ethics \& the spirit of capitalism).

Hegemoni dunia barat mengatakan bahwa keberadaan ajaran agama yang dianut masyarakat justru menjadi penghambat dari mundurnya sistem sosialpolitik-hukum-budaya-ekonomi yang ada di masyarakat. Juga, sebab dari 


\section{Anis Ulfiyatin}

tertinggalnya peradaban di negara timur. Karena mengasumsikan bahwa ilmu pengetahuan tidak dapat berjalan bersama sama dengan keberadaan suatu agama.

Karakteristik dari spirit kapitalisme modern sendiri adalah sebagai berikut: (1) Usaha-usaha ekonomi yang diorganisir dan dikelola secara rasional; (2) Berkembangnya produksi untuk pasar (tagline kapitalisme: bagaimana caranya agar supaya mesin produksi mereka dapat terus berputar dan berjalan?! Caranya, menciptakan kebutuhan hidup manusia, berinovasi dalam memproduksi kebutuhan secara terus menerus); (3) Produksi untuk massa dan melalui massa; (4) Produksi untuk uang (banyak sekali semboyan hidup kaum kapitalis barat yang kemudian menjadi jargon untuk tujuan motivasi dalam mengumpulkan kekayaan dan meningkatkan etos kerja masyarakat, misalnya: time is money, credit is money, money grow money!); dan terakhir, (5) Adanya etos kerja yang menuntut pengabdian manusia pada panggilan kerja (vocational ethics). Kerja adalah sesuatu yang melekat di dalam eksistensi hidup manusia.

Dalam tulisannya, Weber mengajukan sebuah pertanyaan: kekuatan macam apakah sesungguhnya yang telah menyebabkan terjadinya transformasi umat manusia dan tingkah laku sedemikian itu?. Hal ini kemudian mampu dijawab oleh Weber dengan sangat cerdas!. Bahwa sebelum upaya untuk membumikan konsep kapitalis ini dapat dijalankan, individu dalam masyarakat patutlah memiliki karakteristik psikologis tertentu yang nantinya akan mendorong seseorang untuk sampai pada dimilikinya sebuah etos kerja yang mengacu pada etika kapitalisme, sehingga berkembanglah paham kapitalis modern!.

Dalam sistem ajaran agama Protestan sendiri, Tuhan dianggap sebagai yang Maha Esa, penguasa dunia, Sang Pencipta. Tuhan telah menentukan akhir dari pada kehidupan semua umat manusia, dan pembebasan manusia hanya dapat diperoleh melalui anugerah Tuhan. Oleh karena itu, manusia harus menjauhi kesenangan dunia dan hidup hemat demi mendapatkan anugerah Tuhannya. Salah satunya adalah memenuhi panggilan Tuhan untuk bekerja. Konsep kerja, oleh penganut protestan disebut sebagai "the calling!", sebuah panggilan Jihad. "Panggilan suci" bagi kehidupan manusia. 
Simpulan ini menjadi kerangka daripada ajaran agama Protestan. (hasil kajian pada banyak agama lain di pelbagai negara Inggris, Jerman, Belanda, dll.) bahwa dalam etika Protestan, bekerja dan berusaha merupakan panggilan agama. Kesuksesan di dunia dikatakan sebagai representasi dari kebahagiaan hidup di akhirat. Karenanya, penganut Protestan Calvinis ini berusaha semaksimal mungkin untuk bisa bekerja sekuat tenaga dengan keras demi mencapai kesuksesan di dunia sehingga juga bisa sukses nantinya di kehidupan akhirat.

Meskipun demikian, Tesis Weber ini pun tidak lepas dari kritik sesama sosiolog maupun ilmuwan bidang sosial lainnya. Weber memang diakui telah berhasil dalam upaya untuk menjelaskan kontribusi agama terhadap perkembangan perilaku ekonomi khususnya kapitalisme. Weber berhasil menunjukkan bahwa perubahan masyarakat Barat menuju kemajuan ekonomi tidak hanya disebabkan oleh kelompok bisnis dan pemodal.

Dalam penelitiannya, sebagian dari nilai keberagamaan Protestan memiliki aspek rasionalitas ekonomi dan nilai-nilai tersebut ditunjukkan pada spirit keagamaan. Sayangnya, agama Islam tidak mendapatkan perhatian dalam penelitian ini. Bahkan karena pengaruh orientalisme pada masa itu, Weber cenderung bias dalam melihat dan mengkaji ajaran agama Islam. Karenanya, adalah tidak benar bahwa Islam tidak mendorong penganutnya untuk mempunya etos kerja yang tinggi serta etika yang baik.

Sebagaimana dikatakan oleh Taufik Abdullah (1979) dalam bukunya yang berjudul; Agama, Etos Kerja, dan Perkembangan Ekonomi, ia mengatakan bahwa, etika yang dipancarkan oleh Al-Qur'an hampir tak berbeda jauh dengan yang disebut Weber dalam Etika Protestan: jujur, kerja keras, berperhitungan, dan hemat. Bahwa Islam juga menganjurkan penganutnya untuk bekerja keras guna memperoleh kehidupan dunia dan akhirat sekaligus. Dalam Islam, antara kehidupan dunia dan akhirat harus seimbang satu sama lain. Bahkan, pekerjaan dunia yang diniatkan untuk memberikan nafkah kepada keluarga merupakan ibadah yang besar pahalanya di sisi Allah SWT. 


\section{Anis Ulfiyatin}

Lebih dari itu, ada banyak ibadah dengan pahala tinggi yang mempersyaratkan kekayaan duniawi. Misalnya zakat, haji, sedekah, dan infak fì sabỉlillāh. Dimana, dalam pelaksanaan ibadah-ibadah tersebut tidak mungkin dapat dilakukan oleh orang yang tidak mempunyai kekayaan duniawi. Adapun etos kerja, jujur, dan hemat merupakan etika yang memang sangat dijunjung tinggi dalam Islam. Islam mengedepankan etos kerja yang tinggi.

Dalam agama islam pun, ada adagium yang populer tentang hal ini. Misalnya adagium tentang kesungguhan yang berbunyi, "man jadda wajada”, yang artinya: barangsiapa yang bersungguh sungguh maka ia akan berhasil. Atau, sebuah hadist yang diriwayatkan oleh Imam Baihaki yang berbunyi: "Bekerjalah untuk duniamu seolah-olah kamu akan hidup selama-lamanya dan bekerjalah untuk akhiratmu seolah-olah kamu akan mati besok pagi”.

Karenanya dapat dipahami bahwa secara konseptual, Islam justru mendorong penganutnya untuk memiliki etos kerja yang tinggi dalam ekonomi. Kaum muslim dituntut untuk kaya agar bisa mengabdi untuk agama dan juga bisa berbagi dengan yang lainnya. Di sinilah kiranya letak perbedaan kapitalisme dengan konsep ekonomi Islam. Dalam Islam, prinsipnya adalah keadilan dan pemerataan. Kepemilikan terhadap kekayaan dibenarkan bagi siapa saja, namun dari harta yang dimiliki tersebut sebagian harus disisihkan untuk orang miskin. Karena pada prinsipnya di dalam konsep ideal Islam, tak ada orang miskin, yang ada adalah orang yang "cukup”, yang bisa memenuhi kebutuhan pokok dalam hidupnya.

Berbeda dengan kapitalisme yang mementingkan pengumpulan kapital an sich, dalam ekonomi Islam ada beberapa prinsip mendasar yang tidak boleh dilanggar, semisal prinsip kehalalan, larangan adanya monopoli dan penimbunan, larangan eksploitasi sumber daya alam yang dapat merusak lingkungan, serta hal-hal lain tidak selaras dengan prinsip maqāsid sari ‘’ah Islam.

\section{G. Peran Agama dan Pengaruhnya Terhadap Masa Depan Manusia}

Pertanyaan selanjutnya adalah, bagaimana dengan peran ajaran agama dan pengaruhnya terhadap masa depan manusia modern hari ini? Jika beratus ratus 
tahun yang lalu hasil dari berbagai kajian sosial telah menunjukkan adanya pengaruh ajaran agama terhadap perilaku dan tindakan sosial masyarakat, juga menjadi faktor penting terjadinya suatu perubahan di dalam masyarakat, maka tidak menutup kemungkinan, hari ini dan juga di masa yang akan datang, peran suatu ajaran agama yang ada di masyarakat, khususnya adalah agama Islam, berikut produk agamanya, Al-Qur'an, justru akan menjadi penentu daripada laju perubahan sosial dan proses kemajuan peradaban manusia di era modern ini.

Dari sini kita tahu bahwa di masa-masa yang akan datang, tidak menutup kemungkinan peran agama dan produk ajarannya (Al-Qur'an) justru akan semakin besar dan kembali mendapatkan legitimasi dari masyarakat. Bahwa ketika pendekatan-pendekatan lain (ekosospolhum) tidak mampu untuk memberikan kepastian keamanan dan jaminan sosial bagi masyarakat, agama justru tampil menjadi jalan keluar yang paling sempurna. Islam bahkan mampu berkontribusi dalam upaya memurnikan kembali nilai-nilai dari ajaran Islam.

Kajian-kajian sosial di bidang sosiologi agama dengan metodologi penelitiannya, akan mampu memberikan sumbangan bagi proses kemajuan peradaban manusia di masa yang akan datang. Karena dari berbagai kajian sosiologi ini, ia akan dapat berfungsi sebagai daya ramal - yang bersumber pada data lapangan dan mengikuti daripada metodologi penelitian ilmiah yang dapat dipertanggungjawabkan - atas berbagai permasalahan sosial yang ada.

Sumbangan lain dari disiplin sosiologi, bahwa hasil-hasil kajian ilmiah yang dilakukannya akan dapat berfungsi sebagai social engineering. Sebuah upaya ilmiah guna melakukan rekayasa sosial dan memberikan sumbangan pemikiran untuk berbagai kebijakan publik bagi pemerintahan yang ada.

\section{H. Corona Sebagai Mekanisme Memurnikan Kembali Sebuah Agama}

Seorang antropolog berkebangsaan Inggris yang bernama Edward Burnett Tylor (1832-1917) dengan karya spektakulernya, Primitive Culture (1871). Ia hadir sebagai seorang ilmuwan di bidang sosial yang menentang pandangan tradisional tentang teori asal-usul sebuah agama. Tylor menegaskan bahwa untuk mempelajari 


\section{Anis Ulfiyatin}

asal-usul agama kita harus mendapatkan data (etnografi) yang menyeluruh tentang suatu kebudayaan dalam segala bagian komponennya. Metode ini mengharuskan seorang ilmuwan sosial untuk mampu meneliti tindakan-tindakan, kebiasaan, ideide, dan adat istiadat yang dimiliki oleh sebuah masyarakat. Oleh karena itu kajian etnologi menjadi sedemikian penting untuk dapat mengungkap posisi sebuah agama dalam suatu masyarakat.

Dengan kata lain, untuk dapat mendefinisikan apa itu agama dan bagaimana posisinya di masyarakat, kita diharuskan untuk melihat dan meneliti bagaimana para penganut agama tersebut dalam mengejawantahkan berbagai tindakantindakan mereka yang berhubungan dengan perilaku keagamaan, melalui berbagai kebiasaan (folkways) dalam kehidupan sosial masyarakat sehari-hari, melalui ideologi-ideologi keagamaan yang berkembang, dan melalui berbagai adat istiadat yang mengatur tata cara praktik ritual keagamaan yang dilaksanakan pada masingmasing masyarakat di mana mereka tinggal.

Secara sosiologis, pemahaman seperti ini membawa konsekuensi pada munculnya kedudukan sebuah agama yang (hanya) dimaknai sebagai sebuah lembaga sosial biasa dan tidak jauh berbeda dengan lembaga-lembaga sosial lainnya, seperti misalnya lembaga hukum, lembaga ekonomi, lembaga pendidikan, dan lain-lain. Di mana tingkat popularitas, kemajuan, dan tinggi rendahnya legitimasi yang dimiliki sebuah agama di mata masyarakat, seakan-akan dapat ditentukan hanya dengan mengukur tinggi rendahnya kuantitas penganut yang dimilikinya, ditentukan dari ada atau tidaknya adat istiadat yang mengatur tata cara ritual keagamaan yang dimilikinya, dan dari bagus tidaknya ideologi keagamaan yang berkembang di tengah-tengah masyarakatnya.

Bahayanya, pemahaman atas definisi agama yang seperti ini akan menggiring kita pada upaya pengerdilan atas konsep agama ini sendiri secara umum di masyarakat. Dan sadar atau tidak, selama ini kita telah terlanjur terjerumus dan berada pada track pemahaman yang sama.

Oleh karena itu, patutlah kita bersama-sama bersyukur atas kedatangan pandemi Corona (Covid-19) ini. Karena melalui hadirnya momentum wabah 
penyakit yang menggejala di seluruh belahan dunia ini, kita sama-sama disadarkan untuk kembali pada jalan yang benar, bahwa jika selama ini kita terlanjur mengikuti arus yang mendefinisikan agama sebagaimana dalam penjelasan di atas, maka kita akan menuju kepada sebuah titik akhir dari agama itu sendiri. Bahwa agama ternyata bisa berakhir dan mati ketika praktik-praktik ritual keagamaan telah memudar, rapuh, dan bahkan hilang di masyarakat. Sebagaimana hukum yang juga mungkin berlaku pada lembaga-lembaga sosial lainnya ketika tidak lagi difungsikan di lingkungan sosial di mana mereka tinggal.

Corona (Covid-19) mengajak kita bersama-sama, mengupayakan sebuah misi mulia untuk memurnikan kembali agama kita. Bahwa realitas sosial apa pun, di belahan bumi mana pun, dengan konsekuensi ledakan destruksi (sosial, ekonomi, politik, budaya, hukum) seburuk apapun, tidak ada yang boleh menggeser posisi dan keberadaan hakikat Tuhan itu sendiri.

Masyarakat-agama selanjutnya dipaksa untuk bernalar bahwa keberadaan Tuhan justru ada pada realitas sosial kita hari ini. Dia ada di tengah kondisi individu dalam masyarakat yang sedang terisolasi secara sosial, Tuhan hadir dalam tatanan struktur sosial yang mengunci kebebasan berinteraksi sosial dengan sesama, dan Tuhan menampakkan hakikat-Nya dalam perilaku keagamaan yang paling privat dan tersembunyi dari diri masing-masing individu dalam masyarakat-agama.

Akhirnya, melalui telaah ilmiah ini, mari bersama-sama menyelami makna hakiki dari kejadian pandemi Corona (Covid-19) ini. Mari kita manfaatkan momentum \#dirumahaja dengan banyak berkontemplasi, mengisi waktu dengan semakin mendekatkan diri kepada Tuhan kita, dan ber-tafakkurdalam-dalam untuk menjawab pertanyaan paling mendasar dalam hidup: Dimanakah sejatinya Tuhan berada?.

\section{Kesimpulan}

Sebagaimana kita ketahui bersama bahwa pikiran manusia hanya dapat menjangkau dan mampu memecahkan masalah yang bersifat materi, tetapi manusia tidak hanya membutuhkan sesuatu yang bersifat materi saja. Bahwa segi spiritual tidak kalah penting. Bahkan bagi orang yang sampai pada tingkat yang sempurna, 


\section{Anis Ulfiyatin}

segi spiritual lebih penting dari segi materiel. Sehingga se-modern-modernnya manusia, ia akan terus dan tetap membutuhkan agama. Bahkan jika manusia ingin mencapai kemajuan ilmu pengetahuan dan teknologi yang tinggi serta canggih juga masih membutuhkan agama agar ilmu pengetahuan dan teknologi yang digapainya tidak akan membinasakan manusia dan alam lingkungan di mana manusia menjadi bagian yang tak terpisahkan, sama sama sebagai makhluk Allah dan manusia sebagai khalifah-Nya di muka bumi.

Di masa-masa yang akan datang, tidak menutup kemungkinan peran agama dan produk ajarannya (Al-Qur'an) justru akan semakin besar dan kembali mendapatkan legitimasi dari masyarakat. Bahwa ketika pendekatan-pendekatan lain (ekosospolhum) tidak mampu untuk memberikan kepastian keamanan dan jaminan sosial bagi masyarakat, agama justru tampil menjadi jalan keluar yang paling sempurna.

\section{Daftar Pustaka}

Al-Hakim, Sayid Mundzir. Seri 14 Tauladan Abadi: Muhammad Rasulullah SAW Sang Adiinsan. Jakarta: Nur Al-Huda, 2015.

Al Jauhari Mahmud, Muhammad, dkk. Membangun Keluarga Qur'ani, Panduan untuk Para Muslimah. Jakarta: Amzah, 2005.

A.M. Sardiman. Interaksi dan Motivasi Belajar Mengajar. Bandung: Rajawali Pers, 2007.

Cernea, Michael M., Ed., Mengutamakan Manusia di dalam Pembangunan, Jakarta: UI Press, 1988.

Creswell JW. Penelitian Kualitatif dan Desain Riset, Memilih di antara Lima Pendekatan:Edisi III. Yogyakarta: Pustaka Pelajar, 2015.

Desmita. Psikologi Perkembangan Peserta Didik, Panduan bagi Orang Tua dan Guru dalam Memahami Psikologi Anak Usia SD, SMP dan SMA. Bandung: Remaja Rosdakarya, 2012.

Djokosurjo, ed. Agama dan Perubahan Sosial, Yogyakarta: LKPSM, 2001.

Fakih, DR. Mansour. Runtuhnya Teori Pembangunan dan Globalisasi, Yogyakarta: Pustaka Pelajar, 2008.

Hairina, Yulia."Prophetic Parenting Sebagai Modal Pengasuhan dalam Pembentukan Karakter (Akhlak) Anak”. Studia Insania. Vol. 4. No. 1. Hal. 81. 
Hamka, Prof. Dr. Tafsir al-Azhar. Jakarta: Pustaka Panjimas, 1982.

Husin, Abdullah. Model Pendidikan Luqman al-Hakim. Kajian Tafsir Sistem Pendidikan Islam dalam Surah Luqman. Yogyakarta: Insyira, 2013.

Khalid, Amru. Semulia Akhlak Nabi. Solo: Aqwam, 2006.

Lajnah Pentashihan Mushaf Al-Qur'an. Mengenal Ayat-ayat Sains dalam AlQur'an: Jilid 1. Jakarta: Widya Cahaya, 2014.

Lajnah Pentashihan Mushaf Al-Qur'an. Tafsir Al-Qur'an Tematik: Jilid 3. Jakarta: Kamil Pustaka, 2018.

Lajnah Pentashihan Mushaf Al-Qur'an. Tafsir Al-Qur'an Tematik: Jilid 8. Jakarta: Kamil Pustaka, 2018.

Lauer, Robert H. Perspektif Tentang Perubahan Sosial, Jakarta: Rineka Cipta, 2003.

Mashud Msi, Drs. Musta'in. Hand Out Mata Kuliah Perilaku Menyimpang, Surabaya: Universitas Airlangga, 2007,

Poloma, Margaret M. Sosiologi Kontemporer. Jakarta: Raja Grafindo Persada, 2007.

Sofia, Adib. Metode Penulisan Karya Ilmiah. Yogyakarta: Karya Media, 2012.

Totten, dan Beling. Modernisasi: Masalah Model Pembangunan, Jakarta: Rajawali, 1980. 